Dialectologia 26 (2021), 27-44.

ISSN: 2013-2247

Received 13 September 2018.

Accepted 22 November 2018.

\title{
RIVER BASIN DIALECT: INTERNAL RECONSTRUCTION CONSONANT ANCIENT OF JUGRA DIALECT
}

\author{
Rahim Aman, ${ }^{1}$ A. H. Shahidi, ${ }^{2}$ A. S. Rusydiah, ${ }^{3}$ M. F. Fatin Hakimah, ${ }^{4}$ S. Miss Deela, ${ }^{5}$ R. \\ SUHAILAH, ${ }^{6}$ A. B. NOORANiza, ${ }^{7}$ O. NAZIHAH NAJW ${ }^{8} \&$ C. MUMAD ${ }^{9}$ \\ Malay Excellence and Sustainable Heritage Centre / Universiti Kebangsaan Malaysia, \\ Bangi, Selangor, Malaysia * \\ tuntas@ukm.edu.my, ${ }^{1}$ zedic@ukm.edu.my, ${ }^{2}$ deyyasalem910703@gmail.com,3 \\ fatinhakimah@gmail.com, ${ }^{4}$ adila23144@gmail.com, ${ }^{5}$ suhailahruslan@gmail.com, ${ }^{6}$ \\ nooraniza23@gmail.com, ${ }^{7}$ nazihah_najwa@yahoo.com ${ }^{8,}$ mumad16124@gmail.com ${ }^{9}$
}

\section{Abstract}

The purpose of this study is to reconstruct the consonants of the Ancient Jugra Dialect (AJD) that exist in the state of Selangor. The reconstruction of AJD was conducted using the qualitative comparison method. Reconstruction of the consonant was using the internal reconstruction method. The reconstruction criteria used was specifying the cognate word, search for the correspondence device to determine phoneme recurrence and to obtain the ancient phonemes. Three Selangor Jugra variants (JV) were studied, namely the variants of Sungai Buaya (SB), Pulau Nyatoh (PN) and Kelanang (KLNG). The result of this study has proven that the reconstructed AJD has 18 consonant phonemes, that is $*_{\mathrm{p}}, *_{\mathrm{b}}, *_{\mathrm{t}}, *_{\mathrm{d}}, *_{\mathrm{k}}, *_{\mathrm{g}}, *_{\mathrm{\gamma}}$, $*_{\mathrm{h}},{ }^{*} \mathrm{~s},{ }_{\mathrm{t}} \mathrm{f},{ }^{*} \mathrm{~d}_{3},{ }^{*} \mathrm{~m}, *_{\mathrm{n}}, *_{\mathrm{n}}, *_{\mathrm{n}}, *_{\mathrm{l}}, *_{\mathrm{w}}, *_{\mathrm{j}}$. The presence of these ancient phonemes, namely consonant phonemes are regular and predictable. The existence of several innovative features in 5 consonant phonemes, that is, ${ }^{*} \mathrm{p},{ }^{*} \mathrm{t},{ }^{*} \mathrm{k},{ }^{*} \mathrm{\gamma},{ }^{*} \mathrm{~h}$, at certain distribution positions is a feature illustrating that the phenomenon of innovation is likely to be caused by migration and local progress factors.

\footnotetext{
* Faculty of Social Sciences and Humanities, Universiti Kebangsaan Malaysia, 43600, Bangi, Selangor, Malaysia.
} 


\section{Keywords}

reconstruction, qualitative comparison, Jugra, internal reconstruction, innovation

\section{EL DIALECTO DE LA CUENCA DEL RÍO:}

\section{RECONSTRUCCIÓN INTERNA DE LAS CONSONANTES DEL ANTIGUO DIALECTO JUGRA}

\section{Resumen}

El objetivo de este estudio es reconstruir las consonantes del antiguo dialecto Jugra (AJD) que se habla en el estado de Selangor. La reconstrucción de AJD se ha realizado mediante los métodos de comparación cualitativa. La reconstrucción de las consonantes se ha efectuado mediante el método de reconstrucción interna. El criterio de reconstrucción ha consistido en especificar el cognato, buscar el mecanismo de correspondencia para determinar la recurrencia del fonema y obtener los fonemas antiguos. Se han estudiado tres variantes del dialecto Jugra de Selangor (JV), a saber, las variantes de Sungai Buaya (SB), Pulau Nyatoh (PN) y Kelanang (KLNG). El resultado de este estudio ha demostrado que el AJD reconstruido tiene 18 fonemas consonantes: *p, *b, *t, *d, *k, *g, *y, *h, *s, *t $\int{ }^{*} d_{3}, * m, * n, * n, * \eta, * I, * w$, *j. La presencia de estos antiguos fonemas consonánticos es regular y predictible. La existencia de varias características innovadoras en 5 fonemas consonánticos, es decir, ${ }^{*} p,{ }^{*} t,{ }^{*} k,{ }^{*} \gamma^{*} h$, en ciertas posiciones de distribución es una característica que ilustra que es probable que el fenómeno de la innovación sea causado por la migración y por factores del progreso local.

\section{Palabras clave}

reconstrucción, comparación cualitativa, Jugra, reconstrucción interna, innovación

\section{Introduction}

The state of Selangor is located in the middle of west coast of Peninsular Malaysia. Selangor is bordered by Perak to the north, Pahang to the east and Negri Sembilan to the south. Selangor is located in the western part of the Titiwangsa Range. According to the Selangor's official portal, Selangor is generally irrigated by four major river basins, namely the Langat River Basin and Klang River Basin in the south, the Bernam River Basin and Selangor River Basin which is the largest river in Selangor. These major rivers are seen as the main factor of the early community settlement around the areas. Selangor divided its state into nine districts, namely Sabak Bernam, Hulu Selangor, Kuala Selangor, Gombak, 
Klang, Petaling, Hulu Langat, Kuala Langat and Sepang. The early state administrative centre was originally in Kuala Selangor, founded by Raja Lumu or known as Sultan Sallehuddin in 1756.

Bukit Jugra was originally named Tanjung Kera, however, after Sultan Sir Abdul Samad settled in Tanjung Kera, its name was changed to Bandar Temasya (Source obtained from the information at the Jugra Insitu Museum). Jugra covers the area of Bukit Jugra, Kampung Sungai Arak bordering Kelanang and Chodoi Town. The villages selected in this study are Kampung Sungai Buaya, Kampung Kelanang, Kampung Pulau Nyatoh, Kampung Katong, Kampong Sungai Arak, Chodoi, Kampung Teluk Pulai, Bandar, Kampung Sungai Igat, Kampung Permatang Pasir and Kampung Sungai Raba. Based on these villages there are three Jugra variants that can be identified. This situation is clearly different from the Collins' findings $(1989,1996)$ and Djaswadi (2013).

Jugra is one of the areas under Kuala Langat District. The total population of Kuala Langat District is over 200,000 people. The total population of Jugra is recorded at 10,089 in 2015 with the majority being Malays, followed by Chinese and Indians and a small number of Orang Asli. Based on the record stated in the Kuala Langat District official portal, Kuala Langat District covers an area of 857.65 square kilometers, an equivalent to 85,775 hectares. The area under the administration of the local authority is 62,294 square kilometers and the external area under the administration of Kuala Langat District Council is 10 square kilometers. Jugra is $18,533,410$ hectares wide. ${ }^{1}$

\section{Research problem and objective}

The emergence of scholarly experts who are struggling with language-related descriptions are widespread with various issues highlighted in certain areas. One of the areas analyzed by researchers is the field of dialectology. Indeed, the study of Selangor Malay dialect has not been widely conducted by the previous researchers (Collins 1896). When viewed from the early researchers who conducted the studies on Selangor dialect,

\footnotetext{
${ }^{1}$ Cf. <http://www.selangor.gov.my/kualalangat.php/pages/view/19? $\mathrm{mid}=42>$.
} 
they often examine the historical aspects such as Winstedt (1934), Gullick (1993), Adil (1971), Ahmad (1986), Samad Ahmad (1996), and Hassan (1983, 2012). Hence, there are only two researchers who studied on the linguistic of Selangor dialect, namely Omar (1985) and Collins (1996).

The development of dialect study in the 20th century has slightly opened the hearts of the researchers regardless of local or foreign researchers to study the Selangor dialect. The Selangor dialect researched by Omar (1985) is the first research conducted. The study by Omar (1985) is related to an effort to classify the Selangor dialect into two groups, namely the subdialect of Kuala Lumpur and the subdialect of west Selangor. Omar (1985) has divided the areas covering Kuala Lumpur subdialect and West Selangor subdialect. Unfortunately, Omar (1985) does not state which areas are being specifically studied and only made a general grouping which is clearly seen as not really accurate.

The study by Collins (1996) examines the Selangor dialect through a survey in Jugra by identifying the characteristics of the phonetic in Jugra. The locations of the study are Kelanang, Permatang Buah, Pulau Nyatuh in Kelanang subdistrict and Kampung Air Tawar, Katung, Gelanggang Buaya, Sungai Buaya Ujung, Sungai Arak, Bandar and Sungai Igat in Mukim Bandar.

Looking at both studies presented by Omar (1985) and Collins (1996), it is identified that the phonological aspect studied in the Selangor dialect was not given a thorough research compared to other Malay dialects. The researchers had only listed the phonological aspect of the Selangor dialect system but did not look into detail the aspect of reconstruction. Therefore, it is clear that our research has proven that Selangor has its own dialect form like other states. The main objective of this writing is: 1) To describe the phonology of the Jugra Dialect variant, and 2) To reconstruct of the Ancient Jugra dialect.

\section{Research methodology}

This study examines the variation of the Malay language Jugra dialect. The research methodology used in this study is the qualitative method. Among the methods used are literature and fieldwork methods. Literature is a method of collecting information from 
library sources (Reddy 2011) such as scientific books, theses, journals, seminar papers and any material that provides information related to Jugra Malay dialect. Fieldwork involves the location of the study, informant selection, data collection techniques, data analysis and presentation.

The location of this study is the Jugra district. The villages that were used as the study areas are Kampung Sungai Buaya, Kampung Pulau Nyatoh, Kampung Sungai Raba, Chodoi, Kampung Kelanan, Kampung Katong, Kampung Teluk Pulai, Kampung Sungai Arak, Bandar, Kampung Sungai Igat, and Kampung Permatang Pasir. Based on these villages, three Jugra variants have been found, namely the Sungai Buaya variant (SB), the Pulau Nyatoh (PN) variant and the Kelanang variant (KLNG). Among the villages representing SB variants are Kampung Sungai Buaya, Kampung Teluk Pulai, Kampung Sungai Arak, Bandar and Kampung Sungai Igat. The PN variant consists of Kampung Pulau Nyatoh, Kampung Permatang Pasir, Kampung Sungai Raba, Kampung Katong and Chodoi. KLNG variant is only represented by Kampung Kelanang.

The informant's selection is usually based on the NORM and NORF criteria (Chambers \& Trudgill 1998). The data collection methods are the spoken and review methods (Mahsun 2005). While the data collection techniques are interview, picture assignment, writing and recording (Aman et al. 2015, 2017). The presentation and analysis of the data were used to examine every aspect of the language phenomenon studied.

\section{Literature review}

The study presented by Collins (1996) is related to the Malay dialect research by conducting a survey on Jugra. Hence, the difference demonstrates the importance of Jugra's variant grouping and the construction of the history of the development and dissemination of the Malay language. Only two aspects of phonology are emphasized by the researcher that is the vowel sound and final consonant. In terms of the vowel sound aspect, the researcher identified seven phonemes: /i/, /e/, /ع/, /ə/, /a/, /o/, and /u/. The 
phoneme /a/ shows many allophones. In the initial and middle of the word, /a/ exists as the low central vowel [a]; likewise, if /a/ exists in the quarter-final end with a non-glottal consonant. In terms of consonant sound, there are only three main elements emphasized, that is $/ \gamma /$ and its allophones, the discrepancy of the end of word stop form, and end of word $/ \mathrm{s} /$.

Omar's (1985) main aim was to identify the existing Malay dialects. Researchers have listed some dialect systems, namely Kelantan dialect, Terengganu dialect, Sarawak dialect, Selangor dialect and so forth. However, this study will only discuss on the Selangor dialect. Initially, the researchers grouped the Selangor dialect into two groups according to the subdistricts, Kuala Lumpur subdialect and west Selangor subdialect. The Kuala Lumpur subdialect is located below the eastern subarea which spread from Petaling and Ulu Langat in the south, covering the area of Kuala Lumpur and moving north to Ipoh. Meanwhile, the western Selangor subdialect is covered by the western sub-area that extends from the south of the Selangor river to the south covering the district of Kuala Langat. The determination of the subarea's subdialect of West Selangor includes Kelang. Nowadays Kelang is a mixed area that many of its population are immigrants who speak Javanese language. However, Omar has considered Kuala Lumpur subdialect as the basic subdialect.

Furthermore, Omar (1985) had compared the phonological aspect between Kuala Lumpur subdialect with the western Selangor subdialect. Comparative findings between these two subdialects have shown that there are three main features that distinguish the subdialects. First, the pronunciation of $/ \mathrm{h} /$ at the initial of a word. In the western Selangor subdialect /h/ was dropped while in the Kuala Lumpur subdialect the consonant is retained in the initial of word. For example, itam (western Selangor subdialect) and hitam (Kuala Lumpur subdialect) for the word hitam. Second, the removal of $/ \mathrm{h} /$ at the end of word preceded by $\mathrm{o}$, in the western Selangor subdialect, but in the Kuala Lumpur subdialect this does not occur. For example, tujo (western Selangor subdialect) and tujoh (Kuala Lumpur subdialect) for the word tujoh. Third, the recognition of the sequence of /ar/ in the end of word in the subdialects. In the Kuala Lumpur subdialect, / $r$ / has disappeared without affecting a phonetic value of a like the Johore Bahru Subdialect. 


\section{Research approach}

In order to achieve this reconstruction goal, AJD phonemes are shown using the internal reconstruction (Hasrah et al. 2013, 2014). In addition, the AJD word form is also shown in consonance with the reconstruction of the phonemes. The reconstruction method of an ancient language has the following criteria (Crowley 1992, Campbell 2001, Ringe \& Eska 2013):

i. Determine the cognate words from multiple descendant languages as the comparable language. If the cognate words are not obtained or have a completely different form, then this would mean that the word may be descended from other ancient language sources. If the comparable words are cognate, then we must determine the degree of similarity of the form and meaning.

ii. Compiling the language sound correspondence sets which were compared.

iii. Specifies the ancient phonemes from any set of correspondence device. For each set of the sound correspondence device, the determination of ancient phoneme should be performed, that is, the phonemes that are deemed to descend the phonemic correspondence device in the Jugra dialect variant. A set of phonemic correspondence device will descend only one ancient phoneme.

Research on the determination of an ancient phoneme is not an easy task. The phoneme reconstruction stage requires some of the following principles to be considered. According to Aman (2008) and Aman et al. (2018) in his study of the Bidayuh and Iban comparative linguistics:

i. The reconstruction must look at reasonable sound changes, which is a common sound change that occurs in all languages of the world.

ii. A phoneme whose distribution is the most abundant in the descendant languages can be considered as a linear reflection of the ancient phoneme.

iii. The reconstruction must fill the empty space in a phonological system of a language rather than creating a disproportionate phonological system in that language.

iv. An ancient phoneme cannot be reconstructed until the phoneme really exist and can be proven in the decadent languages. Therefore, based on the reconstruction 
approaches by Crowley (1992) and Campbell (2001), the reconstruction of vowel phonemes and diphthong of the Ancient Melanau language (BMLP) can be performed.

\section{Data presentation and discussions}

Comparative results of sound compatibility and subsequently the reconstruction results on variants in Jugra such as Sungai Buaya, Pulau Nyatoh, and Kelanang show the ancient dialect that become the source of the variant's descendant or the abbreviation of

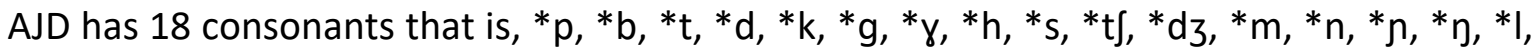
$* \mathrm{w},{ }_{\mathrm{j}}$.

Voiceless bilabial plosive consonant ${ }^{*} p$, is present in all word positions that is, in the initial of the word, the middle of word or the intervocalic and the end of word. The results of this reconstruction show that AJD * $p$ is a direct reflex from MP * p. Following are some examples showing the presence of AJD *p (Table 1).

\begin{tabular}{|l|c|c|c|c|}
\hline AJD & ${ }^{*}$ petai & ${ }^{*}$ kapon & ${ }^{*}$ kətupat & ${ }^{*}$ tijup \\
\hline Meaning & petai & vilage & ketupat & blow \\
\hline SB & petai & kapon & kətupat & tijop \\
\hline PN & petai & kapon & kətupat & tijup \\
\hline KLNG & petai & kapon & kətupat & tijop \\
\hline
\end{tabular}

Table 1. Reconstruction of consonant phoneme AJD *p

Voiced bilabial plosive consonant, ${ }^{*} \mathrm{~b}$ is only present in the initial and middle of $a$ word. This consonant is not reconstructed at the end of word before the silence due to the emergence of / b/ in the Malay language only exist in words borrowed from the Arabic language (Adelaar 1992). The result of this reconstruction shows that AJD ${ }^{*} b$ is a direct reflex from MP*b. Following are some examples showing the presence of AJD*b (Table 2). 


\begin{tabular}{|l|c|c|c|c|}
\hline AJD & *bale? & ${ }^{*}$ ayu & ${ }^{*}$ kəmbว & ${ }^{*}$ sabet \\
\hline Meaning & back & new & twin & crescent \\
\hline SB & bale? & bayu & kəmba & sabet \\
\hline PN & bale? & bayu & kəmbว & sabet \\
\hline KLNG & bale? & bayu & kəmbว & sabet \\
\hline
\end{tabular}

Table 2. Reconstruction of Consonant Phoneme AJD *b

Voiceless alveolar plosive consonant $*_{\mathrm{t}}$, is present in all word positions that is, at the initial of word, middle of word, and end of word. By setting *t as an ancient phoneme of AJD, its ancestors can be traced, which is the direct descendant of MP*t. Following are some examples showing the presence of AJD *t (Table 3).

\begin{tabular}{|l|c|c|c|c|}
\hline AJD & ${ }^{*}$ tenkap & ${ }^{*}$ nanti & ${ }^{*}$ batan & ${ }^{*}$ yabo? \\
\hline Meaning & window & later & stick & hair \\
\hline SB & tenkap & nanti & batan & yabo? \\
\hline PN & tenkap & nanti & batan & abo? \\
\hline KLNG & tenkap & nanti & batan & yabo? \\
\hline
\end{tabular}

Table 3. Reconstruction of consonant phoneme AJD *t

Voiced alveolar plosive consonant, $* d$ is present in the initial word position, middle, intervocalic and after nasal. By setting * $d$ as the AJD ancient phoneme, its descendant can be traced, that is a direct descendant of MP*d. Following are some examples showing the presence of AJD *d (Table 4).

\begin{tabular}{|l|c|c|c|c|}
\hline AJD & ${ }^{*}$ deyah & ${ }^{*}$ dudo? & ${ }^{*}$ pandan & *pədas \\
\hline Meaning & area & sitting & look & spicy \\
\hline SB & deyah & dudo? & pandan & pədas \\
\hline PN & daeyah & dodo? & pandan & pədas \\
\hline KLNG & deyah & dudo? & pandan & pədas \\
\hline
\end{tabular}

Table. 4 Reconstruction of consonant phoneme AJD *d

Voiceless velar plosive consonant ${ }^{*} \mathrm{k}$ is present in the initial word position, intervocalic and the middle of word. The result of this reconstruction shows that AJD *k is 
a direct reflex from $M{ }^{*}{ }^{*}$. Following are some examples showing the presence of AJD ${ }^{*} \mathrm{k}$ (Table 5).

\begin{tabular}{|c|c|c|c|c|}
\hline AJD & *kunĩn & * pankal & *mũkə & *pokวn \\
\hline Meaning & area & sitting & look & spicy \\
\hline SB & kunĩn & pankal & mũkə & pokวn \\
\hline PN & kunẽn & pankal & mũkə & pokən \\
\hline KLNG & kunĩn & pankal & mũkə & pokən \\
\hline
\end{tabular}

Table 5. Reconstruction of consonant phoneme AJD *k

Voiced velar plosive consonant ${ }^{*} \mathrm{~g}$ is present in the initial word position, after the nasal sound and intervocalic. The result of this reconstruction shows that AJD ${ }^{*} \mathrm{~g}$ is a direct reflex MP* ${ }^{*}$. Following are some examples showing the presence of AJD ${ }^{*} g$ (Table $6)$.

\begin{tabular}{|l|l|l|l|l|}
\hline AJD & ${ }^{*}$ gulaj & ${ }^{*}$ dzinga & ${ }^{*}$ pəgi & ${ }^{*}$ pag \\
\hline Meaning & curry & orange & go & fence \\
\hline SB & gulaj & dzinga & pəgi: & paga \\
\hline PN & gulaj & dzinga & pəgi & pagว \\
\hline KLNG & gulaj & dzinga & pəgi & pag \\
\hline
\end{tabular}

Table 6. Reconstruction of consonant phoneme AJD ${ }^{*} \mathrm{~g}$

Voiceless alveolar fricative consonant ${ }^{*} s$, is present in the initial word position, intervocalic, end of words and after the nasal. The result of this reconstruction shows that AJD * $\mathrm{s}$ is a reflex directly from MP*s. Following are some examples showing the presence of AJD *s (Table 7).

\begin{tabular}{|l|c|c|c|c|}
\hline AJD & *səyai & *ansə & *posat & *kabos \\
\hline Meaning & lemonade & goose & center & mist \\
\hline SB & səyai & ansə & posat & kabos \\
\hline PN & səyai & ansə & posat & kabos \\
\hline KLNG & səyai & ansə & posat & kabos \\
\hline
\end{tabular}

Table 7. Reconstructions of consonant phoneme *s

The voiced velar fricative consonant ${ }^{*} \gamma$ is present in the initial word position, intervocalic, and end of word. The result of this reconstruction shows that AJD *y is a 
Dialectologia 26 (2021), 27-44.

ISSN: 2013-2247

direct reflex from MP ${ }^{*} \gamma$. Following are some examples showing the presence of AJD ${ }^{*} \gamma$ (Table 8).

\begin{tabular}{|c|c|c|c|c|}
\hline AJD & *yumput & *yenãn & *seyon & *uyat \\
\hline Meaning & grass & mild & slanting & vein \\
\hline SB & yumput & yenãn & seyon & uyat \\
\hline PN & yumput & yenãn & seyon & uyat \\
\hline KLNG & yumput & yenãn & seyon & uyat \\
\hline
\end{tabular}

Table 8. Reconstructions of consonant phoneme ${ }^{*} \gamma$

Voiceless glottal fricative consonant ${ }^{*} \mathrm{~h}$ is present at the intervocalic and in the end of word. The result of this reconstruction shows that AJD ${ }^{*} h$ is a direct reflex MP ${ }^{*} h$. Following are some examples showing the presence of AJD *h (Table 9).

\begin{tabular}{|l|c|c|c|c|}
\hline AJD & *hile & ${ }^{*}$ lehe & ${ }^{*}$ pəhə & ${ }^{*}$ mãyah \\
\hline Meaning & downstream & neck & thigh & angry \\
\hline SB & hile & lehe & pəhə & mãyah \\
\hline PN & hile & lehe & pəhə & mãyah \\
\hline KLNG & hile & lehe & pəhə & mãyah \\
\hline
\end{tabular}

Table 9. Reconstructions of consonant phoneme ${ }^{* h}$

Voiceless palatal plosive $*_{\mathrm{t}} \int$ is present in the initial word position and intervocalic. The result of this reconstruction shows that AJD $* \mathrm{t} \int$ is a direct reflex from MP ${ }^{*} \mathrm{t}$. Following are some examples showing the presence of AJD *t (Table 10).

\begin{tabular}{|c|c|c|c|c|}
\hline AJD & *t/ərmẽn & *tләуаһ & 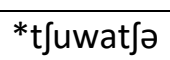 & *kətfi? \\
\hline Meaning & mirror & bright & weather & small \\
\hline SB & tfərmẽn & tjəyah & 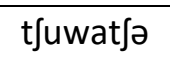 & kətfi? \\
\hline PN & tfərmẽn & tjəyah & 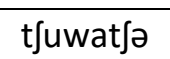 & kətكi? \\
\hline KLNG & tfərmẽn & tjəyah & 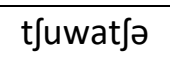 & kətfi? \\
\hline
\end{tabular}

Table 10. Reconstructions of consonant phoneme AJD *t 
Voiced palatal plosive consonant ${ }^{*} \mathrm{~d} 3$ is present in the initial word position, in the middle of a word, and intervocalic. The result of this reconstruction shows that AJD ${ }^{*} \mathrm{~d} 3$ is a direct reflex from $M P * d 3$. Following are some examples showing the presence of AJD *d3 (Table 11).

\begin{tabular}{|l|c|c|c|c|}
\hline AJD & *dzəyəbu & *dzatoh & *təydzun & *udzon \\
\hline Meaning & haze & fall & jump & tip \\
\hline SB & dzəyəbu & dzatoh & təydzun & udzon \\
\hline PN & dzəyəbu & dzatoh & təydzun & udzon \\
\hline KLNG & dzəyəbu & dzatoh & təydzun & udzon \\
\hline
\end{tabular}

Table 11. Reconstructions of consonant phoneme AJD * d3

Bilabial nasal consonant ${ }^{*} m$ is present in the initial position of a word, in the middle of a word, intervocalic and end of word. The result of this reconstruction shows that AJD ${ }^{*} \mathrm{~m}$ is a direct reflex from MP ${ }^{*} \mathrm{~m}$. Following are some examples showing the presence of AJD *m (Table 12).

\begin{tabular}{|l|c|c|c|c|}
\hline AJD & ${ }^{*}$ mũkə & ${ }^{*}$ yumput & ${ }^{*}$ yimãu & ${ }^{*}$ mĩnõm \\
\hline Meaning & face & grass & tiger & drink \\
\hline SB & mũkə & yumput & yimãu & mĩnõm \\
\hline PN & mũkə & yumput & yimãu & mĩnõm \\
\hline KLNG & mũkə & yumput & yimãu & mĩnõm \\
\hline
\end{tabular}

Table 12. Reconstructions of consonant phoneme AJD *m

Alveolar nasal consonant ${ }^{*} n$ is present in the initial word position, intervocalic and in the end of word. The result of this reconstruction shows that AJD ${ }^{*} n$ is a direct reflex from MP ${ }^{*}$. Following are some examples showing the presence of AJD *n (Table 13).

\begin{tabular}{|l|c|c|c|c|}
\hline AJD & ${ }^{*}$ nãlajan & *banda & *bunว̃h & *bulan \\
\hline Meaning & fisherman & town & kill & moon \\
\hline SB & nãlajan: & banda & bunว̃h & bulan \\
\hline PN & nãlajan & bandว & buñ̃h & bJlan \\
\hline KLNG & nãlajan & bandว & bunว̃h & bolan \\
\hline
\end{tabular}


Dialectologia 26 (2021), 27-44.

ISSN: 2013-2247

Table 13. Reconstructions of consonant phoneme AJD *n

Velar nasal consonant ${ }^{*} \eta$ is present in the middle and in the end of word position. The result of this reconstruction shows that AJD ${ }^{*} \eta$ is a direct reflex from a MP ${ }^{*} \eta$. Following are some examples showing the presence of AJD *n (Table 14).

\begin{tabular}{|c|c|c|c|c|}
\hline AJD & *pingan & *banõn & *bəlakan & *pandan \\
\hline Meaning & dishes & wake up & back & look \\
\hline SB & pingan & banõn & bəlakan & pandan \\
\hline PN & pingan & banõn & bəlakan & pandan \\
\hline KLNG & pingan & banõn & bəlakan & pandan \\
\hline
\end{tabular}

Table 14. Reconstruction of consonant phoneme AJD * $\eta$.

Palatal nasal Consonant ${ }^{*} \mathrm{n}$ is only present in the intervocalic position. The result of this reconstruction shows that AJD *n is a direct reflex from a MP *n. Following are some examples showing the presence of AJD *n (Table 15).

\begin{tabular}{|l|c|c|}
\hline AJD & ${ }^{*}$ mĩnã? & $*^{*}$ sũnĩ \\
\hline Meaning & oil & quiet \\
\hline SB & mĩnã? & sũnĩ \\
\hline PN & mĩnã? & sũnĩ \\
\hline KLNG & mĩnã? & sũnĩ \\
\hline
\end{tabular}

Table. 15 Reconstruction of consonant phoneme AJD *n

Voiced lateral consonant $* I$ is present in the initial word position, intervocalic, and end of word. The result of this reconstruction shows that AJD ${ }^{*} I$ is a direct reflex from a MP *I. Following are some examples showing the presence of AJD *I (Table 16).

\begin{tabular}{|l|c|c|c|c|}
\hline AJD & *limə̃ & *lutot & ${ }^{*}$ təlo & *pankal \\
\hline Meaning & five & knee & eggs & base \\
\hline SB & limə̃ & lutot & təlo & pankal \\
\hline PN & limə̃ & lutot & təlo & pankal \\
\hline KLNG & limə̃ & lutot & təlo & pankal \\
\hline
\end{tabular}


Table 16. Reconstruction of consonant phoneme AJD *I

AJD ${ }^{*} w$ semivowel phoneme is only present at the intervocalic position. The result of this reconstruction shows that $A J D * w$ is a direct reflex from a MP ${ }^{*} w$. Following are some examples showing the presence of AJD *w (Table 17).

\begin{tabular}{|l|c|c|c|c|}
\hline AJD & *awan & *bowah & *sawe? & *luws \\
\hline Meaning & cloud & down & palm oil & outside \\
\hline SB & awan & bowah & sawe? & luws \\
\hline PN & awan & bowah & sawe? & luws \\
\hline KLNG & awan & bowah & sawe? & luws \\
\hline
\end{tabular}

Table 17. Reconstruction of consonant phoneme AJD *w

Semivowel consonant phoneme AJD $*_{j}$ is only present at the intervocalic position. However, there are words which show the occurrence of a phonological process called the glide insertion in an intervocalic/middle of word position. The result of this reconstruction shows that $A J D *_{j}$ is a direct reflex from a MP $*_{j}$. Following are some examples showing the presence of AJD *j (Table 18).

\begin{tabular}{|l|c|c|c|c|}
\hline AJD & ${ }^{*}$ kaju & ${ }^{*}$ lojan & ${ }^{*}$ bijasə & ${ }^{*}$ nãlajan \\
\hline Meaning & cloud & down & palm oil & outside \\
\hline SB & kaju & lojan & bijasə & nãlajan \\
\hline PN & kaju & lojan & bijasə & nãlajan \\
\hline KLNG & kaju & lojan & bijasə & nãlajan \\
\hline
\end{tabular}

Table 18. Reconstruction of consonant phoneme AJD *j

Consequently, the consonant inventory that existed in the Ancient Jugra dialect which is seen to be very similar to the consonant inventory of the Peninsular Malay dialects especially the northern variation such as Perak and Kedah dialects. This is because, in this study the use of consonant $/ \mathrm{\gamma} /$ completely eliminate the sound of $[r]$ in the consonant figure of the Jugra Malay Dialect. It has many similarities with most of the basic words of the Malay dialects in the Peninsular that show the common features with the local dialects that is under the Malay cluster. 
The consonant phoneme in the Ancient Jugra Dialect also descends the innovation forms such as the AJD vowel phoneme. However, not all AJD consonant phonemes are experiencing the innovation. Only three consonant phonemes are experiencing the sporadic innovation, that is the consonant phoneme ${ }^{*} \mathrm{p},{ }^{*} \mathrm{t}$ and ${ }^{*} \mathrm{k}$, which become the glottal stop sound [?] for the final position of a closed word. The voiceless velar fricative consonant ${ }^{*} h$ and voiced velar fricative ${ }^{*} \gamma$ did experience the elimination. The voiceless velar fricative consonant ${ }^{*} \mathrm{~h}$ experienced the elimination in the initial of a word for example, the word 'hidup' became [idop] in the AJD. The voiced velar fricative consonant $*_{\gamma}$ is experiencing elimination in the initial of word and intervocalic, for example in the word 'rambut' became [ambo?] and 'gerbang' became [gəbay].

Voiceless plosive consonant AJD * $p$ is appropriately descended in all variants in the initial position and the middle of the word. However, in the end of word, a small innovation occurs sporadically when in all variants * $p$ [?]. The sample data as follows:

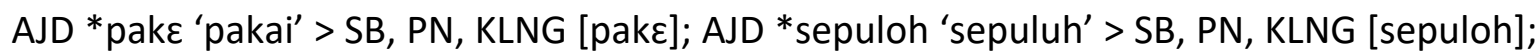
AJD *yədop 'redup' > SB, PN [yədop]; KLNG [yudup]; and AJD *tanka? 'tangkap' > SB [nanka?]; PN, KLNG [tanka?].

Voiceless alveolar plosive consonant AJD $*_{\mathrm{t}}$ is appropriately descended in all variants at the initial and middle of word position. However, in the end of word position, a small innovation occurs sporadically when in all variants $*_{t}>[?]$. The data as follows: AJD *tanam 'tanam' > SB, PN, KLNG [tanam]; AJD *lutot 'lutut' > SB, PN, KLNG [lutot]; AJD *uyat 'urat' > SB, PN, KLNG [uyat]; and AJD *ikJ? 'ikut' > SB, PN, KLNG [ikJ?].

Voiceless velar plosive consonant AJD * $k$ is appropriately descended in all variants at the initial and middle of word position. However, in the end of word position, a small innovation occurs sporadically when in all variants $*_{t}>[\tilde{u}]$. The data as follows: AJD *kəytas 'kertas' > SB, PN, KLNG [kəytas]; AJD *kalo 'kalau' > SB, PN, KLNG [kalo]; AJD *kaki 'kaki' > SB, PN, KLNG [kaki]; AJD *mankok 'mangkuk' > SB, PN, KLNG [mankok]; and AJD *bale? 'balik' > SB, PN, KLNG [bale?].

Voiceless velar fricative consonant AJD ${ }^{*} \mathrm{~h}$ is appropriately descended in all variants at the middle and end of word position. However, at the initial word position, a small sporadic innovation occurs when in all the variants ${ }^{*} \mathrm{~h}>\mathrm{O}$. Data as follows: AJD *idop 
'hidup' > SB, PN, KLNG [idop]; AJD *bənti 'henti' > SB, PN, KLNG [bənti]; AJD *yumah 'rumah' > SB, PN, KLNG [yumah]; AJD *muyah 'murah' > SB, PN, KLNG [muyah]; and AJD *jatoh 'jatuh' > SB, PN, KLNG [jatoh].

Voiced velar fricative consonant AJD ${ }^{*} \gamma$ is appropriately descended in all the variants at the initial word and middle word position. However, in the end of word position, a small sporadic innovation occurs when in all variants the AJD ${ }^{*} \gamma>0$. Data as follows: AJD *yumpun 'rumpun' > SB, PN, KLNG [yumpun]; AJD *aka 'akar' > SB, PN, KLNG [aka]; AJD *uyat 'urat' > SB, PN, KLNG [uyat]; AJD *gamba 'gambar' > SB, PN, KLNG [gamba]; and AJD *campo 'campur' > SB, PN, KLNG [campo].

Based on the above data and discussions, it can be stated that the Jugra dialect indeed represent the Ancient Selangor dialect which was previously thought as nonexistence. Although there is a mix of the immigrants' languages such as Javanese and Minang languages, the original Selangor dialect with its own ancient characteristic can still be found. As a result of the reconstruction, it can be shown that the Jugra dialect has 18 consonant phonemes. Therefore, this study is potential to have an important impact on the Malay dialectology research especially the reconstruction aspect. Moreover, it can highlight significant indications to the Malay culture vocabulary knowledge heritage.

\section{Conclusion}

In fact, the history of the development of studies on Jugra has been a long span of time since the colonial era, but the studies conducted during that time is more on the study of the history of the opening of Selangor state and Jugra town. During the colonial era in Selangor, the colonial administrators' studies on Jugra was on the need basis, for the sake of knowing the community's social system to ensure the continuity of the colonization. For example, researchers in the colonial era are Gullick (1960), Winstedt (1934), Adil (1971), Yusuf Hassan (1983) and others. However, a comprehensive research on the aspect has not been carried out during the time. Among the researchers who studied the linguistic aspect are Omar (1985) and Collins (1996). The formal research 
focusing on the linguistic aspect by Omar (1985) and Collins (1996) were only recently conducted during the middle and at the end of the 20th century. The studies that covers the reconstruction aspect began in the early 21 st century by the linguists resulting to the birth of a research on Jugra variant, however, this reconstruction study still uses the old method that is the lexicostatistics method.

\section{References}

AdeLAAR, K. A. (1992) Proto-Malayic: The reconstruction of its phonology and parts of its lexicon and morphology, Pacific Linguistics C-119, Canberra: Australian National University.

ADIL, Buyong (1971) Sejarah Selangor, Kuala Lumpur: Dewan Bahasa dan Pustaka.

AHMAD, A. Talib (1986) Perang saudara di Selangor 1869-1873, Kuala Lumpur: Penerbitan Pustaka Antara.

AMAN, Rahim (2008) Linguistik bandingan bahasa Bidayuhik, Bangi: Universiti Kebangsaan Malaysia.

AMAN, Rahim, A. H. SHAHIDI \& Norfazila AB. HAMID (2015) "Rekonstruksi Vokal dan Diftong Bahasa Melanau Purba", GEMA Online Journal of Language Studies, 15 (1), 189-206.

AmAn, Rahim, A. H. ShaHiDI \& Norfazila AB. HAMID (2017) "Varian Dialek Melayu Tioman-AurPemanggil: Analisis Linguistik Bandingan", GEMA Online Journal of Language Studies, 17 (2), 219-244.

AMAN, Rahim, Muhammad NUR LATIF \& A. H. SHAHIDI (2018) Linguistik bandingan bahasa Iban, Bangi: Universiti Kebangsaan Malaysia.

CAMPBeLL, L. (2001) Historical linguistics. An introduction, Cambridge: The MIT Press.

ChAMBERS, J. K. \& P. TRUdGill (1998) Dialectology, Cambridge: Cambridge University Press.

ColuINS, J. T. (1989) "Malay dialect research in Malaysia: the issue of perspective", Bijdragen tot de Taal- Land-en Volkenkunde, 145 (2/3), 235-264.

ColuINS, J. T. (1996) Khazanah dialek Melayu, Bangi: Penerbit Universiti Kebangsaan Malaysia.

CROWLEY, T. (1992) An introduction to Historical Linguistics, Auckland: Oxford University Press.

DJASWADI, Stephanie Prisilia (2013) Makna Daeng Dalam Kebudayaan Suku Makassar, Surabaya: Universitas Airlangga. 
GuLLICK, J. M. (1993) Glimpses of Selangor 1860-1898, Kuala Lumpur: Academe Art \& Printing Services.

HASRAH, Mohd. Tarmizi, A. H. SHAHIDI \& Rahim Aman (2013) "Inovasi dan retensi dalam dialek Hulu Tembeling", Gema Online Journal of Language Studies. 13 (3), 211-222.

HASRAH, Mohd. Tarmizi, A. H. ShaHidI \& Rahim Aman (2014) Fosil dialek Melayu Hulu Pahang, Bangi: Universiti Kebangsaan Malaysia.

HASSAN, Yusoff (1983) Jugra dalam Sejarah, Kuala Lumpur: Penerbitan TRA-TRA.

HASSAN, Yusoff (2012) Sejarah Kuala Selangor, Kelantan: ST Media Resources.

MAHSUN (2005) Metode penelitian bahasa, Jakarta: Grafindo Persada.

OMAR, Asmah (1985) Susur galur bahasa Melayu, Kuala Lumpur: Dewan Bahasa dan Pustaka.

REDDY, R. J. (2011) Research methodology, New Delhi: A P H Publishing Corporation.

RINGE, D. \& J. ESKA (2013) Historical linguistics toward a Twenty-First century reintegration, Cambridge: Cambridge University Press.

SAMAd AHMAD, Abdul (1996) Pesaka Selangor, Kuala Lumpur: Dewan Bahasa dan Pustaka.

WINSTEDT, R. O. (1934) A History of Selangor, Singapore: Malaya Publishing House.

<http://www.selangor.gov.my/kualalangat. php/ pages/view/19? Mid=42> (accessed on 24 June 2018). 